\title{
ГЕНДЕРНЫЙ АСПЕКТ ЗАНЯТОСТИ ПРЕДПЕНСИОНЕРОВ
}

\author{
(c) 2019 Сафина Лилия Моратовна \\ старший преподаватель кафедры финансовых рынков и финансовых институтов \\ Института управления, экономики и финансов \\ Казанский федеральный университет, Россия, Казань \\ E-mail: lilisafina1@gmail.com \\ (c) 2019 Кузнецова Алсу Мунировна \\ кандидат социологических наук, старший преподаватель кафедры управления \\ человеческими ресурсами Института управления, экономики и финансов \\ Казанский федеральный университет, Россия, Казань \\ (c) 2019 Рыжова Ася Сергеевна \\ ассистент кафедры управления человеческими ресурсами \\ Института управления, экономики и финансов \\ Казанский федеральный университет, Россия, Казань
}

В статье рассматривается актуальный вопрос занятости лиц предпенсионного возраста, а также меры по сохранению занятости для данной категории граждан с учетом гендерных различий. Выявлено, что в долгосрочной перспективе для повышения гарантий занятости и сокращения уровня бедности предпенсионеров необходимо учитывать специфику занятости мужчин и женщин при разработке программ переобучения.

Ключевые слова: качество жизни, качество трудовой жизни, занятость предпенсионеров, гендерные различия.

Демографические реалии современного мира характеризуются глобальным процессом старения населения. Это ставит перед обществом новые вопросы практической оценки влияния этого фактора на качество жизни населения в целом и отдельных групп. Если на первых этапах идентификации проблема старения определяла научную дискуссию по вопросу организации социальной защиты и досуга новой когорты, то в настоящее время становится очевидным, что необходим поиск вариантов реализации занятости этой группы населения, как определяющей в концепции качества трудовой жизни в частности и качества жизни общества.

В связи с реализацией Правительством РФ модели пенсионной реформы с поэтапным повышением пенсионного возраста исследование вопроса занятости предпенсионеров в разрезе гендерных различий является актуальным.

Данные, представленные в таблице 1, показывают, что на протяжении последних 10 лет численность населения за границами трудоспособного возраста устойчиво возрастала, увеличившись с 30,5 миллиона человек на начало 2009 года до 38 миллионов в 2019 году, что составило
$26 \%$ населения страны.

Анализ динамики численности мужского и женского населения за пределами трудоспособного возраста, показывает, что с 2009 по 2019 годы численность мужчин выросла с 8,3 млн. до 11,4 млн. в 2019 году, что составило 16\% мужского населения страны, тогда как численность женщин в этот же период возросла с 21,8 млн. до 26,5 млн. и составила $34 \%$ женского населения страны. Как видно, за пределами трудоспособного возраста четко прослеживается гендерное различие в численности населения.

В отношении предпенсионеров на базе официальной статистической информации сделать точный вывод о наличии четкого гендерного различия для лиц предпенсионного возраста не представляется возможным в связи со спецификой предоставления статистической информации, например, сборник «Женщины и мужчины России» (где представлена статистическая информация по показателям, характеризующим положение женщин и мужчин в России) издается с периодичностью один раз в два года. Тем не менее, мы можем предположить, что в границе предпенсионного возраста приближенной к мо- 
Таблица 1. Распределение численности населения по группам в предпенсионном и пенсионном возрасте в России, на 1 января 2019 года (тыс. чел) [5]

\begin{tabular}{|c|c|c|c|}
\hline Возраст, лет & Все население & Мужчины & Женщины \\
\hline $55-59$ & 10811 & 4824 & 5987 \\
\hline $60-64$ & 10027 & 4174 & 5853 \\
\hline $65-69$ & 8179 & 3144 & 5034 \\
\hline $70-74$ & 4635 & 1645 & 2990 \\
\hline 75 и выше & 11281 & 2972 & 8309 \\
\hline Все население & 146781 & 68096 & 78684 \\
\hline \multicolumn{4}{|l|}{ Из общей численности - население в возрасте: } \\
\hline мужчины и женщины 0-15 & 27430003 & 14076112 & 13353891 \\
\hline мужчины 16-59, женщины 16-54 & 81361671 & 42575353 & 38786318 \\
\hline мужчины 60 и более, женщины 55 и более & 37989046 & 11444962 & 26544084 \\
\hline
\end{tabular}

менту выхода на пенсию общий тренд неравновесного распределения численности мужчин и женщин с преобладанием последних сохраняется. Если это предположение верное, то встает вопрос, что именно в мерах, предпринимаемых в рамках проводимой пенсионной реформы и сдвига границ пенсионного возраста, направлено на решение вопроса гарантирования занятости с учетом существенного гендерного разрыва в численности предпенсионеров.

Предлагаемый комплекс мер поддержки занятости предпенсионеров, на наш взгляд, носит общий характер, не отражающий гендерных различий, а именно Пенсионный фонд совместно с центрами занятости населения с 2019 года предоставляют предпенсионерам повышенное пособие по безработице (в объеме не ниже МРОТ) и занимаются программами профессионального переобучения и повышения квалификации предпенсионеров, ориентируя их на имеющийся в регионах контент образовательных программ. По планам, в период с 2019 по 2024 годы переобучение ежегодно будут проходить по 75 тысяч человек, что позволит охватить в рамках проекта не менее 450 тысяч предпенсионеров. Фактически речь идет обо всех предпенсионерах без уточнения кого именно планируется переобучать: мужчин или женщин. Такие программы обучения предпенсионеров в первую очередь будут нацелены на формирование востребованных компетенций в рамках имеющейся занятости, а не на формирование новых навыков и знаний, хотя возможна и такая траектория, если в ней заинтересован предпенсионер. Интересным на этом фоне является решение о привлечении площадок WorldSkills, на общем фоне предлагаемых однотипных программ переобучения, но там также нет уточнения на кого в большей степени рассчитано переобучение на мужчин или женщин. На наш взгляд, такой подход может быть оправдан только при проектировании занятости предпенсионеров в отдельных отраслевых нишах, где обновление структуры рабочих мест и интенсивность движения рабочей силы низкая. На всех остальных сегментах рынка труда предполагаемой занятости предпенсионеров трехмесячное повышение квалификации значительного влияния на перспективность сохранения занятости не окажет.

На занятость предпенсионеров не сможет оказать существенного влияния ни приобретаемые ими навыки при работе с компьютерными программами, интернетом, ни введение норм уголовной ответственности для работодателей за необоснованное увольнение этой категории работников, т.к. фактически отсутствует экономическая заинтересованность работодателей в сохранении рабочих мест за предпенсионерами. Граждане предпенсионного возраста в 2019 году стали новой для России социальной группой с особым трудовым статусом и льготами, точно так же, как в свое время беременные женщины при введении статьи 261 «Гарантии беременной женщине и лицам с семейными обязанностями при расторжении трудового договора» в Трудовой кодекс РФ. Но точно так же, как и с беременными женщинами, практика российского рынка труда, в условиях отсутствия четко выстроенной системы защиты прав работника, будет демонстрировать негласные правила. По принципу, если нет возможности уволить сотрудника, то проще его не принимать на работу, что может создать более высокую угрозу снижения занятости уже при приближении к предпенсионному 
возрасту, т.е. фактически от 45 лет.

При обсуждении вопроса гендерных диспропорций занятости предпенсионеров необходимо обратить внимание на прогнозную динамику численности этой группы, таблица 2.

Ввиду того, что общеустановленный пенсионный возраст будет ежегодно увеличиваться, то и предпенсионный возраст тоже будет постоянно смещаться до 2023 года. Предпенсионный возраст устанавливается за 5 лет до пенсионного возраста, который отличается у граждан разных годов рождения. При определении предпенсионного возраста необходимо ориентироваться именно на дату рождения, иначе может возникнуть путаница, но т.к. в демографическом прогнозе указаны целочисленные значения возраста, кроме того, статус предпенсионера устанавливается для граждан имеющих право на досрочное пенсионное обеспечение в более раннем возрасте, то для предварительного анализа можно ориентироваться на данные с 2023 года.

Начиная с первого января 2023 года к предпенсионерам по общему правилу назначения страховой пенсии в России будут относиться женщины, достигшие возраста 55 лет и мужчины в возрасте 60 лет.

Средний вариант прогноза предполагает, что общая численность населения России сни- зится к началу 2036 года почти до 143 млн. человек, из них 24,1\% составит население старше трудоспособного возраста. При этом, начиная с 2022 года и по 2028 год, будут ощутимы последствия «демографических провалов» девяностых годов XX века, что также отражается на сокращении численности предпенсионеров в этот период. По самому оптимистичному прогнозу численность населения вырастет до 150 млн. человек к 2036 году, по самому пессимистичному варианту численность населения сократится до 134 млн. человек. K моменту завершения переходного периода к 2024 году численность всех предпенсионеров будет сокращаться, но при этом численность женщин - предпенсионеров составит 4,8 млн. человек или $6,1 \%$ от всего среднего прогнозного значения численности женского населения, то численность мужчин предпенсионеров составит 4,3 млн. человек или $6,4 \%$ всего среднего прогнозного значения численности мужского населения. В долгосрочной перспективе при сохранении фиксируемых в российских условиях факторов к 2036 году численность женщин - предпенсионеров вырастет до 5,5 млн. человек (7,2\% численности женского населения), тогда как общая тенденция сокращения численности мужчин - предпенсионеров сохраниться и к 2036 году прогнозируется 4 млн.

Таблиц̧ 2. Численность предпенсионеров по среднему варианту демографического прогноза до 2036 года, человек [4]

\begin{tabular}{|c|c|c|c|c|c|c|c|c|}
\hline \multicolumn{4}{|c|}{ Для мужчин } & \multicolumn{4}{|c|}{ Для женщин } & \multirow[b]{2}{*}{$\begin{array}{c}\text { Год возник- } \\
\text { новения } \\
\text { права на } \\
\text { льготы, } \\
\text { предостав- } \\
\text { ляемые } \\
\text { предпенси- } \\
\text { онерам }\end{array}$} \\
\hline 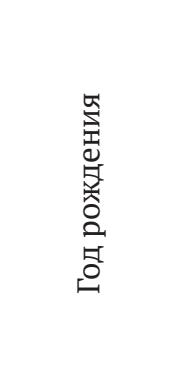 & 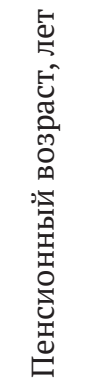 & 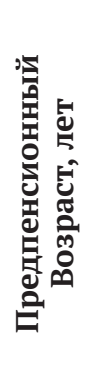 & 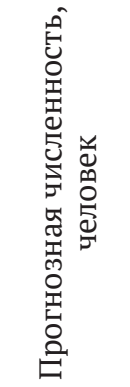 & 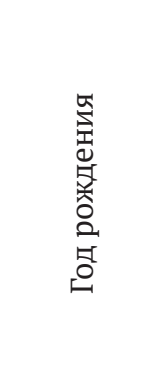 & 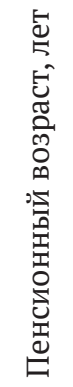 & 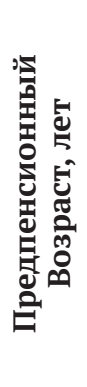 & 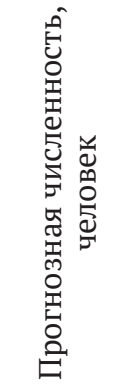 & \\
\hline 1959 & 60,5 & 55,5 & \multirow{3}{*}{ - } & 1964 & 55,5 & 50,5 & \multirow{3}{*}{ - } & \multirow{3}{*}{2019} \\
\hline 1960 & 61,5 & 56,5 & & 1965 & 56,5 & 51,5 & & \\
\hline 1961 & 63 & 58 & & 1966 & 58 & 53 & & \\
\hline 1962 & 64 & 59 & 4531079 & 1967 & 59 & 54 & 5207231 & 2021 \\
\hline 1963 & \multirow{5}{*}{65} & \multirow{5}{*}{60} & 4399192 & 1968 & \multirow{5}{*}{60} & \multirow{5}{*}{55} & 4935995 & 2023 \\
\hline \multirow{4}{*}{1964 и т.д. } & & & 4330698 & \multirow{4}{*}{1969 и т.д. } & & & 4751056 & 2024 \\
\hline & & & 4202605 & & & & 4652592 & 2025 \\
\hline & & & 3539883 & & & & 5048479 & 2030 \\
\hline & & & 4048081 & & & & 5475848 & 2036 \\
\hline
\end{tabular}


мужчин - предпенсионеров (6\% численности мужского населения).

При общей тенденции сокращения численности предпенсионеров, прогнозный уровень бедности предпенсионеров, то есть женщин 55-59 лет и мужчин 60-64 лет, увеличится и составит к 2028 году 7,3\% в умеренном сценарии и до $6,1 \%$ в оптимистичном [1]. Бедность предпенсионеров определяется проблемами в занятости этой категории граждан (по оценкам Пенсионного фонда в 2019 году из 10,1 млн. предпенсионеров России официально работали $40 \%$, из них 1,8 млн. мужчин 1959-1963 годов рождения и 2,2 млн. женщин 1964-1968 годов рождения) и отсутствием дохода в виде пенсионного обеспечения. При этом среди мужчин доля официальной занятости выше и составляет $43 \%$, тогда как у женщин только $38 \%$.

Все вышеперечисленное определяет, что меры направленные на поддержку занятости предпенсионеров безусловно должны учитывать гендерный аспект неравенства в занятости и прогнозную численность мужчин и женщин предпенсионного возраста. Для этого необходимо более точно, с учетом досрочного назначения пенсионного обеспечения, оценить численность предпенсионеров мужчин и женщин в переходный период и до 2036 года. Без этого учета фактически программы повышения квалификации, ориентированные только на мужчин не смогут решить вопрос занятости, например, женщин и наоборот.

Не стоит забывать, что эффективность комплекса предлагаемых мер по улучшению ситуации в переходный период для предпенсионеров вызывает у экспертного сообщества много вопросов, например те же программы повышения квалификации. Так, согласно Приказу Минтруда № 131 от 1 марта 2019 г. по реализации программы переобучения, ее участниками могут стать либо официально работающие, либо нетрудоустроенные, но не признанные официально безработными предпенсионеры среди которых женщин больше. Негативным фактором явля- ется и то, что темпы охвата предпенсионеров переобучением в регионах пока ниже запланированных показателей. Ключевой показатель эффективности программы переобучения предпенсионеров это доля сохранивших занятость предпенсионеров. Из числа прошедших переобучение, занятыми должны быть не менее 85\% охваченных переподготовкой предпенсионеров [3]. В вопросах финансирования региональных программ социальной защиты предпенсионеров также присутствует много проблем [2].

Таким образом, намеченный комплекс мер по сохранению занятости ориентирован на формирование предложения на рынке труда предпенсионеров и поддержание их в случае отсутствия занятости (выплата пособия по безработице, стипендии в период переобучения). Меры, ориентированные на работодателей (в виде ужесточения наказания за необоснованное увольнение предпенсионеров) не окажут, на наш взгляд, существенного воздействия на спрос. По оценке экспертов онлайн-сервиса для оценки персонала Squadrille в 2019 году 56\% российских работодателей были готовы нанимать на работу предпенсионеров. В то же время для недопущения бедности предпенсионеров не достаточно рассчитывать только на перспективу снижения темпов инфляции и экономический рост. Необходимы меры, направленные на повышение заинтересованности работодателей в занятости предпенсионеров путем налоговых и страховых преференций при приеме на работу предпенсионеров, а также поддержание высокого тренда на постоянное повышение квалификации у самих занятых, достигающих определенные возрастные границы. На наш взгляд, если занятый получает второе образование или диплом о профессиональной переподготовке, то социальный налоговый вычет по расходам на обучение должен рассчитываться от 100\% суммы затрат на обучение, включая за рубежом. Все это сформирует основу для более гармоничного развития рынка труда в условиях старения населения с учетом гендерных различий.

\section{Библиографический список}

1. Горлин Ю.М., Карцева М.А., Ляшок В.Ю. Влияние повышения пенсионного возраста на уровень бедности населения РФ: микросимуляционный анализ // Прикладная эконометрика.- 2019._- т. 54. - С. 26-50

2. Региональные аспекты финансирования программ социальной защиты / Л.М. Сафина, Д.М. Сафина, Ч.М. Шавалеева // Экономика в меняющемся мире: III Экономический форум с международным участием (Казань, 17-26 апреля 2019 года): сб. науч. статей / под ред. Н.Г. Багаутдиновой, Л.Н. Сафиуллина.-Казань: Изд-во Казан. ун-та.- 2019.- С. 266-268 
3. Сайт РБК. Минтруд признал недостаточным темп программы переобучения предпенсионеров. [Электронный ресурc] URL: https:/www.rbc.ru/economics/15/04/2019/5caf6ef19a7947fefd8bf61а (дата обращения 20.08.2019)

4. Сайт Федеральной службы государственной статистики. Демографический прогноз до 2035 года. [Электронный ресурc] URL: https://www.gks.ru/folder/12781 (дата обращения 20.01.2020)

5. Сайт Федеральной службы государственной статистики. Демография. Численность и состав населения. [Электронный ресурс] URL: https:/www.gks.ru/folder/12781?print=1 (дата обращения 20.01.2020) 